閉塞性換気障害と拘束性換気障害が疑われる

地域在住高齢者の身体機能の特徵

\title{
Characteristics of the physical function of community-dwelling elderly suspected obstructive ventilatory impairment and restrictive ventilatory impairment
}

\author{
阿波 邦彦 ${ }^{1,2)}$, 村田 伸 ${ }^{1)}$, 岩瀬 弘明 ${ }^{1)}$, 政所 和也 ${ }^{3)}$ \\ 八谷 瑞紀 $^{4)}$, 久保 温子 ${ }^{4)}$, 伊藤 健一 ${ }^{2)}$, 上城 憲司 ${ }^{4)}$, 堀江 淳 $^{1)}$ \\ Kunihiko Anami, 2), Shin Murata ${ }^{1)}$, Hiroaki Iwase' ${ }^{1)}$, Kazuya Madokoro3) \\ Mizuki Hachiy ${ }^{4)}$, Atsuko KubO4), Kenichi Ito²), Kenji KamijO4), Jun Horie ${ }^{1)}$ \\ 要旨：【はじめに】本研究の目的は, 地域在住高齢者に扔ける閉塞性換気障害と拘束性換 \\ 気障害の有症率を明らかにし，正常群を含む 3 群間の身体機能を比較検証することとした。 \\ 【方法】地域在住高齢者 128 名（年齢75.5 5 土. 1 歳）に対し，呼吸機能検査や身体機能を評 \\ 価し，換気障害別の各測定項目を比較した。3 群間の比較は年齢を共変量とする一元配置 \\ 共分散分析で解析し, 各群に拈ける呼吸機能と各測定項目の関係を Pearsonの相関分析 \\ を用いて検討した。 \\ 【結果】正常群は80名 $(68.4 \%)$, 閉塞性換気障害群は14名 $(12.0 \%)$, 拘束性換気障害群 \\ は23名（19.6\%）であった。正常群，閉塞性換気障害群，拘束性換気障害群の 3 群間を比 \\ 較したところ, 呼吸機能に有意差を認めたが,すべての身体機能に有意差は認められなかっ \\ た。ただし，閉塞性換気障害群のみ，呼吸機能と各測定項目に有意な相関を認めた。 \\ 【結論】換気障害の差異で身体機能に有意差は認めないが, 閉塞性換気障害群は呼吸機能 \\ の低下に伴い，筋力が低下する可能性が示された。
}

キーワード：地域在住高齢者, 換気障害の有無, 身体機能

\begin{abstract}
Purpose】 This study aimed to clarify the prevalence of obstructive ventilatory impairment and restrictive ventilatory impairment, as well as to verify physical function among three groups (the obstructive and restrictive ventilatory impairment groups and the normal group) in community-dwelling elderly. 【Methods】 We assessed the results of respiratory function tests and physical function tests in 128 community-dwelling elderly, and compared measurement items of each ventilatory impairment group. Comparisons between three groups were analyzed using one-way analysis of covariance for the covariate of age, whereas the relationships between measurement items and respiratory function in each group were analyzed using Pearson correlation analysis. 【Results】 Subjects consisted of the normal group of 80 people $(68.4 \%)$; obstructive ventilatory impairment group, 14 people (12.0\%); and restrictive ventilatory impairment group, 23 people (19.6\%). Respiratory function showed a significant difference among the three groups, but physical function showed no significant difference. The obstructive ventilatory impairment group showed a significant correlation between respiratory function and physical function. IConclusions】 Different types of ventilation impairment do not cause significant difference in physical function. However, obstructive ventilatory impairment may cause muscle weakness and reduced respiratory function.
\end{abstract}

Key words: community-dwelling elderly, ventilatory impairment, physical function

受付日：2016年 1 月 8 日, 採択日：2016年 2 月 5 日

京都滳大学 健康科学部：京都府京都市山科区大宅山田町34（テ607-8175）電話番号：075-571-1110, FAX 番号：075-574-4314 Eメールアドレス : anami@tachibana-u.ac.jp

Faculty of Health Science, Kyoto-Tachibana University: 34 Oyake-Yamadamachi Yamashina-ku Kyoto-shi Kyoto 607-8175, Japan, Telephone number: $+81-75-571-1110$; facsimile number: $+81-75-574-4314$

E-mail address:anami@tachibana-u.ac.jp

大阪府立大学大学院総合リハビリテーション学研究科

Graduate School of Comprehensive Rehabilitation, Osaka Prefecture University

医療福祉専門学校緑生館 理学療法学科

Department of Physical Therapy, Technical School of Medical and Welfare Ryokuseikan

西九州大学りハビリテーション学部

Faculty of Rehabilitation Science, Nishikyusyu University 


\section{I 、はじめに}

厚生労働省の人口動態統計によると, 肺炎が第 3 位, 慢性閉塞性肺疾患（以下, Chronic obstructive pulmonary disease; COPD）が第10位と呼吸器疾患が死因別

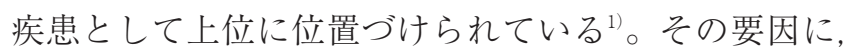
我が国の人口構造が高齢化に大きくシフトしたこと, 加えて, COPD 等を有する低肺機能症例が肺炎の危 険因子であることなどが挙げられる。特に, COPD は肺炎を含む肺感染症を発症しやすく, かつ重症化し やすい状態にある2。。その対策として, COPDの早期 発見 ${ }^{3-5)}$, 拘束性換気障害 6.7 を含吉低肺機能症例を発 見することが重要とされている。

一方，拘束性換気障害は日本人間ドック学会に拐け るガイドラインによると，拘束性換気障害を規定する 予測比肺活量が80\%未満はすべて要生検と判定区分さ れている゙ が，COPD ほど強い関心は寄せられておら ず，さらにはその身体機能を比較検討した報告は少な (い)。

そこで本研究の目的は, 地域在住高齢者の閉塞性換 気障害と拘束性換気障害の有症率を明らかにすること, 呼吸換気機能が正常である群（以下，正常群）, 閉塞 性換気障害群, 拘束性換気障害群の 3 群間の身体機能 を比較検討することとした。異なる換気障害における 身体機能の違いを明らかにし，その換気障害の身体機 能的特徵を検討することは, 地域在住高齢者における 換気障害の早期発見, および呼吸器疾患の注意喚起を 行う上で, 一つの臨床的指針になるものと考える。

\section{II. 研究参加者と方法 \\ 1. 研究参加者}

市主催の健康支援事業に参加した60歳以上の地域在 住高齢者 128 名（平均年齢 $75.5 \pm 6.1$ 歳）を研究参加者 とした。研究参加者には, ヘルシンキ宣言に則り, 事 前に本研究内容を文書と口頭による説明を行い，本研 究の参加に関して文書による同意が得られている者と した。また, 喘息等の呼吸器疾患を有する者, 本研究 に同意が得られない者, 歩行動作等に支障をきたす疾 患や重篤な内部障害を有する者, 重度認知症である者 は本研究から除外した。

\section{2. 方 法}

測定項目は筋力評価として握力, 膝伸展筋力, 上体 起こし，30秒椅子立ち上がりテスト（以下，CS-30）, 呼吸筋力として最大吸気口腔内圧, 最大呼気口腔内圧,
柔軟性評価として長坐位体前屈, バランス評価として 片脚立位時間, Functional reach test (以下, FRT), 歩行能力評価として $10 \mathrm{~m}$ 障害物歩行時間, Timed up and go test（以下，TUG）を測定した。

\section{1 ) 呼吸機能検査}

呼吸機能検查は, スパイロメータ（ミナト医科学社 製オートスパイロ AS-507）を使用し，日本呼吸器学 会の呼吸機能検査ガイドライン に準じて, フローボ リューム曲線を 2 回測定し, 努力性肺活量および予測 努力性肺活量に対する努力性肺活量の比率（予測比努 力性肺活量)， 1 秒量および予測 1 秒量に対する 1 秒 量の比率 (予測比 1 秒量), 1 秒率の最良値を採用し た。閉塞性換気障害は 1 秒率が $70 \%$ 未満の者, 拘束性 換気障害は予測比努力性肺活量が $80 \%$ 未満の者と定義 した。なお，混合性換気障害は 1 秒率が70\%未満かつ 予測比努力性肺活量が $80 \%$ 未満の者とし, 研究参加者 からは除外した。

\section{2 ）筋力評価}

握力は, デジタル握力計 (竹井機器工業製 T.K. K. 5401グリップ-D）を使用し，文部科学省高齢者用 新体力テスト ${ }^{10}$ に準じ, 測定姿位は立位で, 左右とも 2 回測定し，その最大值を採用した。

膝伸展筋力は, 徒手筋力測定装置 (アニマ社製 $\mu$-Tas F-1）を使用し，座位で膝関節を90度屈曲した状態 でセンサーパッドを下腿遠位部にバンドで固定して測 定した。測定は左右ともに 2 回実施し, 計 4 回の最大 值を体重で除した体重比膝伸展筋力を採用した。

上体起こしは，文部科学省高齢者用新体力テスト ${ }^{10}$ に準じ，背臥位で両腕を胸の前で組み，両膝を屈曲 90 度に保持した姿勢から, 両肘が両大腿部に接触するま で上体を起こすように指示し，30秒間に何回起こせる かを測定した。

CS-30は，中谷ら ${ }^{11)} の$ 方法に準じ，背もたれのない $40 \mathrm{~cm}$ 程度の椅子を用い, 両腕を前で組んだ坐位肢位か ら実施した。開始の合図で, 膝関節が完全伸展する立 位肢位から再び着座するまでを 1 回として 30 秒間繰り 返し，その回数を測定した。

\section{3) 呼吸筋力}

呼吸筋力は，スパイロメー夕（ミナト医科学社製； オートスパイロ AS-507）を使用し, 最大吸気口腔内 圧と最大呼気口腔内圧を 2 回測定し, その最大值を採 用した。

\section{4 ) 柔軟性評価}

長座体前屈は, デジタル式長座体前屈測定器（竹井 
機器工業製）を使用し，文部科学省高齢者用新体力テ スト ${ }^{10}$ に準じ，体前屈時の上肢指尖の移動した距離を 測定した。測定は 2 回行い，その最長距離を採用した。 5 ) バランス評価

片脚立位時間の測定は，文部科学省高齢者用新体力 テスト ${ }^{10)}$ に準じ，開眼片脚立位で姿勢保持できる時間 について，120秒を上限としてデジタルストップ ウォッチを用いて測定した。

FRT は, 測定用のメジャーを肩峰の高さで水平に して壁に取り付け, 壁側の上肢を水平に前方挙上し, 安楽に前方・水平に上肢をできるだけ遠くまで伸ばす ように指示した。測定は上肢指尖の移動した距離を 2 回測定し、その最長距離を採用した。

6 ) 歩行能力評価

$10 \mathrm{~m}$ 障害物歩行時間は, 文部科学省高齢者用新体力 テスト ${ }^{10}$ に準じ，スポンジ製の高さ $20 \mathrm{~cm}$ 障害物を 2 $\mathrm{m}$ 間隔で 6 個設置された $10 \mathrm{~m}$ の直線の最速歩行時間を デジタルストップウォッチで測定した。測定は 2 回行 い, 最短所要時間を採用した。

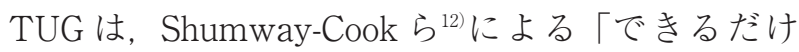
速く」歩行する方法で行い, 高さ $40 \mathrm{~cm}$ 程度の肘掛のな い椅子に腰かけた姿勢から, 開始の合図で起立, 歩行 を開始し， $3 \mathrm{~m}$ 前方のポールを回ってもとの椅子に着 座するまでの時間をデジタルストップウォッチで測定 した。測定は 2 回行い, 最短所要時間を採用した。

\section{3. 統計解析}

3 群間の各測定項目の比較には一元配置分散分析で 解析した。ただし，年齢に有意差を認める場合は，身 体機能等の比較において年齢を共変量とする一元配置 共分散分析で検討することとした。なお，混合性換気 障害群は解析対象には含めなかった。また, 各群にお ける呼吸機能と身体機能との関係を Pearsonの相関 分析を用いて検討した。統計学的有意水準は $5 \%$ とし， 解析ソフトはSPSS ver. 19を用いた。

\section{III. 結 果}

正常群は80名 (68.4\%), 閉塞性換気障害群は14名 (12.0\%), 拘束性換気障害群は23名 (19.6\%) であっ た。なお，除外対象者は混合性換気障害群が 3 名，喘 息の既往を有する者が 3 名, 肺がん手術後の既往を有 する者が 1 名, 歩行に支障を来たす脳血管疾患の既往 を有する者が 3 名, アルッハイマー病の既往を有する 者が1名, 計11名であった。閉塞性換気障害群を
COPD と仮定した場合, Global Initiative for Chronic Obstructive Lung Disease (以下, GOLD) 病期分類 では I 期が 4 名 (28.6\%)，II 期が10名（71.4\%）で あった。拘束性換気障害は予測比努力性肺活量を $10 \%$ ずつ細分化すると $80 \%$ 未満70\%以上が19名 (82.6\%), $70 \%$ 未満60\%以上が 3 名 (13.0\%)，60\%未満が 1 名 (4.3\%) であった。

閉塞性換気障害群の年齢が正常群よりも有意に高 かったため, 年齢を共変量とした一元配置共分散分析 で 3 群間を比較した。その結果, 努力性肺活量と予測 比努力性肺活量は, 正常群に比べ拘束性換気障害群が 有意に低值を認めた。1秒量と予測比 1 秒量は, 正常 群に比べ閉塞性換気障害群, 拘束性換気障害群が有意 に低值であった。また，1秒率は閉塞性換気障害群が 正常群および拘束性換気障害群よりも有意に低值を示 した。なお，呼吸機能以外の身体機能は，すべての測 定項目に有意差を認めなかった（表 1 参照）。

また, 各群における呼吸機能と各測定項目との関係 については, 正常群と拘束性換気障害群では有意な相 関は認められなかったが, 閉塞性換気障害群において, 呼吸機能と筋力や片脚立位時間等に有意な相関を認め た (表 2 参照)。

\section{IV. 考 察}

\section{1 . 換気障害の有症率について}

地域在住高齢者に呼吸機能検査を実施した結果, 閉 塞性換気障害の有症率は $12.0 \%$, 拘束性換気障害の有 症率は19.6\%であった。COPD 有病率は世界12か国 の COPD 疫学調査 ${ }^{13}$ が $10.1 \%$, 我が国で行われた $\mathrm{COPD}$ 大規模疫学調査 ${ }^{5}$ が70歳以上で $17.4 \%$ と報告さ れている。また，小林らうは人間ドックで延べ118, 733 例の $28.8 \%$ に拘束性換気障害が存在すると報告した。 本研究に㧈ける COPD の有症率は先行研究5) 上りも低 かったが，それは市主催の健康支援事業に参加してい る健康意識の高い高齢者であったこと, 先行研究より も若年者が含まれていたことが要因と考えられる。な 扮, 本研究に扔ける拘束性換気障害の有症率は, 先行 研究7 よりも低い有症率ではあったものの, 研究参加 者全体の約 2 割を占めていた。

\section{2. 換気障害別における身体機能の差異について}

COPD は世界に扔ける死因別死亡率でも第 4 位に 位置しているにもかかわらず4)，未受診の COPD 患 者は病気という自覚症状に忘しい上に, 重症化してい 
表 1 . 3 群間における身体機能指標の比較

\begin{tabular}{|c|c|c|c|c|}
\hline & 全体 & 正常群 & 閉塞性換気障害群 & 拘束性換気障害群 \\
\hline & $(\mathrm{n}=117)$ & $(n=80)$ & $(n=14)$ & $(n=23)$ \\
\hline 年齢（歳） & $75.7 \pm 6.2$ & $75.1 \pm 5.8$ & $79.4 \pm 6.8^{*}$ & $75.4 \pm 6.5$ \\
\hline 性別（男／女） & $72 / 45$ & $46 / 34$ & $9 / 5$ & $17 / 6$ \\
\hline 身長（cm） & $157.0 \pm 11.1$ & $157.5 \pm 12.3$ & $156.7 \pm 8.7$ & $155.8 \pm 7.8$ \\
\hline 体重（kg） & $57.7 \pm 9.2$ & $58.1 \pm 9.0$ & $56.5 \pm 8.2$ & $56.7 \pm 10.6$ \\
\hline BMI & $23.4 \pm 3.2$ & $23.6 \pm 3.4$ & $23.0 \pm 2.8$ & $23.2 \pm 3.1$ \\
\hline FVC (L) & $2.49 \pm 0.66$ & $2.61 \pm 0.59$ & $2.59 \pm 0.95$ & $2.02 \pm 0.45^{* *}$ \\
\hline \%FVC (\%) & $91.5 \pm 13.5$ & $96.6 \pm 9.3$ & $94.3 \pm 14.5$ & $72.2 \pm 6.3^{* *}$ \\
\hline $\mathrm{FEV}_{1.0}(\mathrm{~L})$ & $1.95 \pm 0.52$ & $2.10 \pm 0.48$ & $1.65 \pm 0.60^{*}$ & $1.62 \pm 0.38^{* *}$ \\
\hline$\% \mathrm{FEV}_{1.0}(\%)$ & $90.4 \pm 16.5$ & $97.5 \pm 13.7$ & $76.8 \pm 9.0^{*}$ & $73.7 \pm 10.7^{* *}$ \\
\hline 1秒率（\%) & $78.1 \pm 7.6$ & $79.9 \pm 5.4$ & $63.7 \pm 5.1^{*}$ & $80.6 \pm 6.1^{* * *}$ \\
\hline 握力（kg） & $29.5 \pm 8.2$ & $29.6 \pm 8.2$ & $28.2 \pm 7.9$ & $29.9 \pm 8.6$ \\
\hline 膝伸展筋力（kgf） & $21.6 \pm 6.6$ & $21.5 \pm 6.3$ & $21.3 \pm 7.0$ & $22.2 \pm 7.8$ \\
\hline 上体起こし（回） & $7.5 \pm 6.8$ & $8.1 \pm 7.1$ & $6.0 \pm 5.0$ & $6.0 \pm 6.8$ \\
\hline 30秒椅子立ち上がり（回） & $18.8 \pm 5.5$ & $19.6 \pm 5.4$ & $15.1 \pm 5.5$ & $18.0 \pm 5.1$ \\
\hline 最大吸気口腔内圧 $\left(\mathrm{cmH}_{2} \mathrm{O}\right)$ & $52.3 \pm 25.1$ & $53.6 \pm 25.4$ & $53.2 \pm 30.9$ & $47.2 \pm 20.5$ \\
\hline 最大呼気口腔内圧 $\left(\mathrm{cmH}_{2} \mathrm{O}\right)$ & $75.3 \pm 29.9$ & $77.4 \pm 30.5$ & $63.6 \pm 26.8$ & $75.4 \pm 29.1$ \\
\hline 長座体前屈（cm） & $31.6 \pm 9.5$ & $32.5 \pm 9.6$ & $33.3 \pm 10.0$ & $27.5 \pm 8.1$ \\
\hline 片脚立位時間（秒） & $36.8 \pm 38.1$ & $38.8 \pm 37.2$ & $37.6 \pm 43.9$ & $29.2 \pm 38.0$ \\
\hline Functional reach test $(\mathrm{cm})$ & $28.0 \pm 7.6$ & $29.0 \pm 7.4$ & $25.1 \pm 9.2$ & $26.2 \pm 6.8$ \\
\hline 10m障害物歩行時間（秒） & $7.9 \pm 1.6$ & $7.8 \pm 1.5$ & $8.4 \pm 2.2$ & $8.1 \pm 1.5$ \\
\hline Timed up and go test（秒） & $6.3 \pm 1.2$ & $6.2 \pm 1.2$ & $6.8 \pm 1.3$ & $6.4 \pm 1.1$ \\
\hline
\end{tabular}

平均 \pm 標準偏差, ${ }^{*}$ : 正常群 VS 閉塞性換気障害群 $\mathrm{p}<0.05,{ }^{* *}$ : 正常群 VS 拘束性換気障害群 $\mathrm{p}<0.05$,

*** : 閉塞性換気障害群 VS 拘束性換気障害群 $\mathrm{p}<0.05$

年齢，身長，体重，BMI は一元配置分散分析で解析し，その他はすべて年齢を共変量とした一元配置共分散分析 で解析した。なお，混合性換気障害は解析対象としなかった。

BMI : Body mass index, FVC : 努力性肺活量, \%FVC : 予測比努力性肺活量, $\mathrm{FEV}_{1.0}$ : 1 秒量, \% FEV $\mathrm{FV}_{1.0}$ : 予測 比 1 秒量

表 2. 各群における呼吸機能と身体機能指標との関係

\begin{tabular}{|c|c|c|c|c|c|c|c|c|}
\hline & \multicolumn{2}{|c|}{$\begin{array}{c}\text { 全体 } \\
(\mathrm{n}=117)\end{array}$} & \multicolumn{2}{|c|}{$\begin{array}{l}\text { 正常群 } \\
(\mathrm{n}=80)\end{array}$} & \multicolumn{2}{|c|}{$\begin{array}{c}\text { 閉塞性換気障害群 } \\
(\mathrm{n}=14)\end{array}$} & \multicolumn{2}{|c|}{$\begin{array}{c}\text { 拘束性換気障害群 } \\
(\mathrm{n}=23)\end{array}$} \\
\hline & $\% \mathrm{FVC}$ & $\% \mathrm{FEV}_{1.0}$ & $\% \mathrm{FVC}$ & $\% \mathrm{FEV}_{1.0}$ & $\% \mathrm{FVC}$ & $\% \mathrm{FEV}_{1.0}$ & $\% \mathrm{FVC}$ & $\% \mathrm{FEV}_{1.0}$ \\
\hline 握力 & -0.01 & -0.03 & -0.13 & -0.14 & 0.50 & $0.64^{*}$ & 0.25 & 0.06 \\
\hline 膝伸展筋力 & 0.07 & 0.08 & -0.09 & -0.06 & $0.62^{*}$ & $0.69^{* *}$ & 0.24 & 0.28 \\
\hline 上体起こし & 0.09 & -0.02 & -0.10 & $-0.23^{*}$ & $0.62^{*}$ & $0.63^{*}$ & 0.42 & 0.19 \\
\hline 30秒椅子立ち上がり & 0.13 & 0.15 & 0.07 & 0.02 & 0.40 & 0.40 & 0.10 & -0.02 \\
\hline 最大吸気口腔内圧 & $0.20^{*}$ & 0.17 & 0.00 & 0.05 & $0.65^{*}$ & $0.67^{* *}$ & 0.24 & 0.13 \\
\hline 最大呼気口腔内圧 & 0.02 & 0.07 & -0.07 & -0.05 & 0.15 & $0.32^{*}$ & 0.16 & 0.07 \\
\hline 長座体前屈 & 0.16 & 0.09 & 0.03 & 0.01 & 0.05 & 0.12 & -0.04 & -0.11 \\
\hline 片脚立位時間 & $0.26^{* *}$ & 0.10 & 0.13 & -0.04 & $0.66^{* *}$ & $0.65^{*}$ & 0.17 & -0.09 \\
\hline Functional reach test & 0.18 & 0.16 & 0.10 & 0.10 & 0.47 & $0.62^{*}$ & 0.01 & -0.25 \\
\hline 10m 障害物歩行時間 & -0.12 & -0.08 & -0.01 & 0.05 & -0.52 & -0.42 & 0.01 & -0.04 \\
\hline Timed up and go test & -0.07 & -0.11 & -0.01 & -0.02 & -0.32 & -0.18 & 0.07 & -0.10 \\
\hline
\end{tabular}

${ }^{*}: \mathrm{p}<0.05,{ }^{* *}: \mathrm{p}<0.01$

$\% \mathrm{FVC}$ : 予測比努力性肺活量, $\% \mathrm{FEV}_{1.0}$ : 予測比 1 秒量 
るケースも少なくない。Horie ら ${ }^{4)}$ は, 受診を遅らせ ている原因の一つに, 未受診閉塞性換気障害例は呼吸 機能正常例と比べても運動耐容能や筋力等の機能低下 は認められず，日常生活に支障を来たさないことを挙 げている。

本研究でも正常群と閉塞性換気障害群の身体機能に 有意差を認めず, 先行研究と矛盾しない。加えて, 先 の 2 群と拘束性換気障害群に扔いても身体機能に有意 差を認めなかったことは, 地域在住高齢者の呼吸機能 に関する新たな知見といえる。拘束性換気障害には肺 容量の減少を伴う間質性肺炎 ${ }^{15)}$ や肺以外の因子に由来 する神経筋疾患 ${ }^{16,17)}$ 等による呼吸不全がある。これら 疾患による身体機能への障害は報告されているが, 未 受診である拘束性換気障害の身体機能は検討されてい ない。今回，3群間で身体機能に有意差が認められな かったことから，拘束性換気障害も閉塞性換気障害と 同様, 正常群と比較して明らかな身体機能低下が認め られないために，日常生活に支障を来たさず，未受診 に至っているものと推察された。

ただし，各群別に呼吸機能と各測定項目との関係を 確認したところ, 閉塞性換気障害群のみ, 呼吸機能と 筋力や片脚立位時間等に有意な相関を認めた。このこ とから, 閉塞性換気障害群は未受診, 未診断であって も呼吸機能の重症化に伴う, 身体機能の低下が推察さ れる。COPDに打ける筋力低下は, 全身性炎症の影 響等に伴う要因よりも, 廃用性変化の要因が大きいと

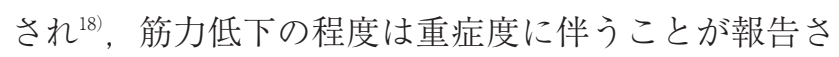
れている ${ }^{19)}$ 。今回, GOLD 病期分類のI 期が多いため 各群で比較すると身体機能に違いはないが, 閉塞性換 気障害群の中だけでみると, 呼吸機能の低下に伴う筋 力低下が出現し始めている可能性が示唆された。これ は, COPD が重症化する前に受診する必要性を示す 一助になりうる。

\section{3. 本研究の限界と今後の課題}

本研究にはいくつかの限界がある。まず第 1 に, 喫 煙状況を聴取できていないことである。COPDをは じめ, 多くの呼吸器疾患は喫煙による影響が多分にあ ることから，哭煙状況を聴取すべきであった。また， 市主催の健康支援事業に参加している高齢者であるた め, 日頃から健康への関心が高く身体活動を積極的に 行っている対象者が多い可能性がある。そのため, 身 体活動が低下している高齢者でも本研究結果と同様の 結果が得られるとは言い難い。今後は, 身体活動量の
低い高齢者や虚弱な高齢者でも今回と同様の結果が得 られるのかについて検証することが課題である。

\section{引用文献}

1. 厚生労働省人口動態統計月報年計の概況. http:www.mhlw. go.jp/toukei/saikin/hw/jinkou/suikei12（accessed 2014 年 5 月25日)

2. Sethi S: Bacterial infection and the pathogenesis of COPD. Chest, 2000, 117 (5 Suppl 1): 286 S-291 S.

3. 及川真人, 千住秀明, 大曲正樹 - 他：一般住民を対象とし たCOPD スクリーニング手段としての修正版 $11-\mathrm{Q}$ の有 用性. 日本呼吸ケア・リハビリテーション学会誌, 2009, 19(1) : 43-47.

4. Horie J, Murata S, Hayashi S, et al: Factors that delay COPD detection in the general elderly population. Respir Care, 2011, 56(8): 1143-1150.

5. Fukuchi Y, Nishimura M, Ichinose M, et al.: COPD in Japan: the Nippon COPD Epidemiology study. Respirology, 2004, 9 (4): 458-465.

6. 山門實, 伊藤千賀子, 大森久光 - 他 : 人間ドック健診成績 判定及び事後指導に関するガイドライン作成委員会報告.

人間ドック，2008，22(5)：865-877.

7. 小林伸行, 都築隆, 萬造寺知子.他：肺活量予測式および \%肺活量判定区分変更による影響. 人間ドック，2011，26 (1) : 100-105.

8. 堀江淳, 阿波邦彦, 今西和也 - 他 : 非呼吸器疾患にて理学 療法を実施している症例の呼吸機能に関する調査. 神戸国 際大学リハビリテーション研究, 2014(5)：27-31.

9. 日本呼吸器学会肺生理専門員会: 呼吸機能検査ガイドライ ンースパイロメトリー, フローボリューム曲線, 肺拡散能 力. 東京：メディカルレビュー社；2004.

10. 文部科学省：新体力テストー有意義な活用のために一。新 体力実施要項65歳 79歳対象, 2010 .

11. 中谷敏昭, 灘本雅一, 三村寛一・他：30秒椅子立ち上がり テスト（CS-30テスト）成績の加齢変化と標準值の作成. 臨床スポーツ医学, 2003, 20(3)：349-355.

12. Shumway-Cook A, Brauer S, Woollacott M: Predicting the probability for falls in community-dwelling older adults using the Timed Up \& Go Test. Phys Ther, 2000, 80(9): 896903.

13. Buist AS, McBurnie MA, Vollmer WM, et al:: International variation in the prevalence of COPD (the BOLD Study): a population-based prevalence study. Lancet, 2007, 370(9589): 741-750.

14. Disease GIfCOP（2011）慢性閉塞性肺疾患のためのグロー バルイニシアティブ日本語版. http://www.goldcopd.org/ uploads/users/files/GOLDReport 2011_Japanese.pdf（accessed2015年 3 月23日)

15. Swigris JJ, Brown KK, Make BJ, et al.: Pulmonary rehabilitation in idiopathic pulmonary fibrosis: a call for continued investigation. Respir Med, 2008, 102(12): 1675-1680.

16. Chio A, Mora G, Leone M, et al.: Early symptom progression rate is related to ALS outcome: a prospective population-based study. Neurology, 2002, 59(1): 99-103. 
17. Berlly M, Shem K: Respiratory management during the first five days after spinal cord injury. J Spinal Cord Med, 2007, 30(4): 309-318.

18. Gosselink R, Troosters T, Decramer M: Distribution of muscle weakness in patients with stable chronic obstructive pulmonary disease. J Cardiopulm Rehabil, 2000, 20(6): 353-360.

19. Bernard S, LeBlanc P, Whittom F, et al.: Peripheral muscle weakness in patients with chronic obstructive pulmonary disease. Am J Respir Crit Care Med, 1998, 158(2): 629-634. 